\title{
Spectroscopic, Thermal, Magnetic and conductimetric studies on some 7-hydroxy-4-methyl-8-(arylazo)coumarins and their complexes with some divalent transition metal ions
}

\author{
S.A. Abdel-Latif ${ }^{\mathrm{a}, *}$, S.E. Mansour ${ }^{\mathrm{b}}$, D.M. Ibrahim ${ }^{\mathrm{b}}$ \\ ${ }^{a}$ Chemistry Department, Faculty of Science, Helwan University, Cairo, Egypt \\ ${ }^{b}$ Chemistry Department, Faculty of Science, Omar Al-Mukhtar University, Albeidaa, Libya
}

\begin{abstract}
L1) and 7-hydroxy-4-methyl-8-(pmethoxyphenylazo)coumarin (L2) have been prepared and characterized by elemental analysis, infrared (IR), proton nuclear magnetic resonance $\left({ }^{l} H\right.$ NMR) and mass spectra. The important infrared (IR) spectral bands corresponding to the active groups in the two ligands and the solid complexes under investigation were studied. Also the important fragments in the ligands and complexes were done using mass spectra and the main peaks were corresponding to the molecular weights of the ligands and complexes. The solid complexes have been synthesized and characterized by elemental and thermal analyses (TG and DTA) as well as by IR, ${ }^{I} H N M R$, magnetic measurements, electronic transition, molar conductance, mass and electron spin resonance (ESR) spectra. The proposed steriochemical structures for the investigated metal complexes suggest octahedral geometry with respect to $\mathrm{Mn}, \mathrm{Co}, \mathrm{Ni}, \mathrm{Cu}$ and $\mathrm{Zn}$ divalent metal ions with the investigated ligands $1: 1$ and 1:2 complexes and all of the formed complexes contain coordinated and hydrated water molecules. All of the prepared solid complexes behave as non-electrolytes in chloroform.

Keywords: Azocoumarins; Complexes; Spectroscopic; Thermal analysis; conductance
\end{abstract}

\section{Introduction}

Coumarin (1,2-benzopyrone), the parent molecule of coumarin derivatives, is the simplest compound of a large class of naturally occurring phenolic substances made of fused benzene and $\alpha$-pyrone rings [1]. The pharmacological and biochemical properties and therapeutic applications of simple coumarins depend upon the pattern of substitution [2]. Monohydroxy compounds containing coumarin nucleus have proved to be of great importance, introduction of azo group to such hydroxy coumarins increases its chelating tendency. From the structural point of view, these compounds were considered as metal indicators as they possess functional groups capable of chelate formation binding directly to the central metal ions. Synthesis of a series of 9 new azocoumarin dyes were reported. These dyes were obtained, confirmed and characterized by using chromatography, elemental analysis, UV-Vis, fluorescence and ${ }^{1} \mathrm{H}$ NMR spectra [3]. The emission characteristics of some 8-(arylazo)-7-hydroxy-4-methylcoumarin have been studied [4]. The action of the coumarin-type drugs and related compounds is reviewed to their antagonistic effects. Twenty 3-pyridinyl, pyrimidinyl and pyrazolyl-4-hydroxycoumarin derivatives were synthesized [5]. The cyclo addition reaction of unsymmetrically $\mathrm{N}$-substituted and $\mathrm{N}$-unsubstituted 1,3-oxazolium-5-olates with selected 3 -substituted coumarins has been examined [6]. The synthesis of novel metal-free and zinc phthalocyanines with four 3-[(2diethylamino)ethyl]-7-oxo-4-methyl- coumarin dye groups on the periphery were prepared by cyclotetramerization of the novel 3-[(2-diethylamino)ethyl]-7-[(3,4-dicyanophenoxy)]-4-methylcoumarin [7]. The novel chromogenic compounds were characterized. A series of new fluorinated coumarins and 1azacoumarins were synthesized and cha racterized[8]. Structural study of supramolecular photochemical $\beta-$ cyclodextrin ( $\beta$-CD)-coumarin derivatives systems and the crystal structure of the $\beta$-CD-4,7-dimethylcoumarin complex has been determined [9]. Two new coumarin derivatives were synthesized and characterized. Their structures were determined by X-ray crystallography single crystal analysis. The fluorescence behaviors of the compounds in dichloromethane solutions were observed [10]. A novel ligand, 7-(2,3-dicyanophenoxy)-3-(2chloro-4-fluorophenyl)coumarin was synthesized [11]. The structure of the compound was confirmed by elemental analysis, UV-Vis, IR, MALDI-TOF mass and ${ }^{1} \mathrm{H}$ NMR spectra.

The present investigation deals with the preparation of some arylazocoumarins and their complexes with divalent $\mathrm{Mn}(\mathrm{II}), \mathrm{Co}(\mathrm{II}), \mathrm{Ni}(\mathrm{II}), \mathrm{Cu}(\mathrm{II})$ and $\mathrm{Zn}(\mathrm{II})$ metal ions. The solid complexes have been prepared and characterized by elemental and thermal analyses (TG and DTA) as well as by IR, ${ }^{1} \mathrm{H}$ NMR, magnetic measurements, electronic transition, molar conductance, mass and electron spin resonance (ESR) spectra to throw more light on the bonds formed and on their structures. 


\section{Experimental}

All chemicals used were of Analar or the highest purity grade from $\mathrm{BDH}$ used as received without further purification. These included manganese (II) chloride $\left(\mathrm{MnCl}_{2} \cdot 4 \mathrm{H}_{2} \mathrm{O}\right)$, cobalt (II) chloride $\left(\mathrm{CoCl}_{2} \cdot 6 \mathrm{H}_{2} \mathrm{O}\right)$, nickel (II) chloride $\left(\mathrm{NiCl}_{2} \cdot 6 \mathrm{H}_{2} \mathrm{O}\right)$, copper (II) chloride $\left(\mathrm{CuCl}_{2} \cdot 2 \mathrm{H}_{2} \mathrm{O}\right)$, zinc chloride $\left(\mathrm{ZnCl}_{2}\right)$, p-toluidine (p-methylaniline), p-ansidine (p-methoxyaniline), sodium hydroxide, ammonium hydroxide $\left(30 \% \mathrm{NH}_{3}\right)$, ammonium chloride, disodium salt of ethylenediamine-tetraacetic acid dihydrate (EDTA), sodium chloride, silver nitrate $\left(\mathrm{AgNO}_{3}\right)$, sulphuric acid $\left(\mathrm{H}_{2} \mathrm{SO}_{4}\right)$, hydrogen peroxide $\left(\mathrm{H}_{2} \mathrm{O}_{2}\right)$ and hydrochloric acid $(37 \% \mathrm{HCl})$. The solvents used were ethanol, chloroform and Dimethylsulphoxide (DMSO). The solvents were purified if needed by distillation.

\subsection{Preparation of ligands $L 1$ and $L 2$}

A well-stirred solution of p-toluidine (p-methylaniline) or p-ansidine (p-methoxy-aniline) (0.01mole in $40 \mathrm{ml}$ ethanol) and $20 \mathrm{ml}$ of $2 \mathrm{M} \mathrm{HCl}$ was cooled in an ice salt bath and diazotized with aqueous sodium nitrite solution $(20 \mathrm{ml}, 0.01 \mathrm{~mol})$. The cooled $\left(0-5^{\circ} \mathrm{C}\right)$ diazonium solution was added slowly to a well-stirred solution of $(0.01 \mathrm{~mol})$ 7-hydroxy-4-methylcoumarin in $(100 \mathrm{ml})$ ethanol containing sodium hydroxide $(0.01 \mathrm{~mol})$. The products were filtered off and recrystallized from absolute ethanol [12]. Elemental analyses for the prepared azocoumarin dyes were done. The results obtained were in good agreement with the calculated values. The structures of these ligands were established by ${ }^{1} \mathrm{H}$ NMR, mass and IR spectral analysis. The prepared azocoumarin dyes have the following structural formulae:<smiles>[X]c1ccc(N=Nc2c(O)ccc3c(C)cc(=O)oc23)cc1</smiles>

$\mathrm{X}=\mathrm{CH}_{3}$, 7-Hydroxy-4-methyl-8-(p-methylphenylazo)coumarin (L1)

$\mathrm{X}=\mathrm{OCH}_{3}$ 7-Hydroxy-4-methyl-8-(p-methoxyphenylazo)coumarin (L2)

Table 1 shows the analytical data of the prepared azocoumarin dyes

\subsection{Preparation of the solid complexes}

The solid complexes were prepared by mixing a hot alcoholic saturated solution of $0.001 \mathrm{M}$ of metal salt solutions with the requisite amount of ligands under investigation ( L1 and L2) sufficient to form 1:1 or 1:2 $(\mathrm{M}: \mathrm{L})$ complexes. The $\mathrm{pH}$ of the solution was then maintained at a value of 5-6 by addition of dilute $(1: 10)$ ammonia solution [13]. The reaction mixture was heated on a steam bath with occasional stirring for $4 \mathrm{hrs}$, and evaporated till dryness. The solid complexes were filtered off and washed several times with ethanol until a colorless filtrate was obtained, suction, filtered and then finally kept in a vacuum desiccator. The metal content of the prepared solid complexes was determined [14].

\section{Apparatus and techniques}

Elemental analysis and all of the other analyses were performed in the Micro-analytical center of Cairo University, Giza, Egypt. The IR spectra were recorded on Shimadzu FTIR-8201 PC spectrophotometer applying the $\mathrm{KBr}$ disc technique. The NMR spectra were measured by using a Varian Gemini $200 \mathrm{MHz}$ spectrophotometer and the solvent used was deutrated DMSO $\left(\mathrm{d}^{6}-\mathrm{DMSO}\right)$. The spectra were extended from (014) ppm using TMS as internal standard. Mass spectra of the coumarin azo dyes and some of their complexes were carried out using Q-1000 EX GC-MS Shimadzu spectrometer at $70 \mathrm{eV}$ and MA energy using a direct insertion probe at temperature $90-110^{\circ} \mathrm{C}$. Thermal analysis (TG and DTA) were obtained in a nitrogen atmosphere using a type TGA 50 Shimadzu derivatograph thermal analyzer. The heating rates were suitably controlled at $10{ }^{\circ} \mathrm{C} \min ^{-1}$ under a nitrogen atmosphere and the weight loss was measured from ambient 
temperature up to $400^{\circ} \mathrm{C}$. The electron spin resonance (ESR) spectra of the copper complexes under study were recorded using EMS ESR spectrometer (Bruker) $1998 \mathrm{Y}$ at Micro analytical center, Cairo University, Giza, Egypt. The molar conductance of the solid complexes in chloroform was measured using a conductivity meter type Philips, PW 9526 digital conductivity meter. The magnetic susceptibility measurements [15] were done using Faraday's method which is the most suitable method for measuring the magnetic susceptibility. The Faraday balance is designed as for solid sample measurements which may be of almost any form, single crystal, and polycrystalline solid, alloys ... etc. The electronic spectra of the investigated azocoumarin dyes and some of their complexes were measured by applying chloroform as solvent using Beckman Coulter DU 800 spectrophotometer using $1 \mathrm{~cm}$ matched silica cells.

\section{Results and discussion}

The solid complexes of $\mathrm{Mn}(\mathrm{II}), \mathrm{Co}(\mathrm{II}), \mathrm{Ni}(\mathrm{II}), \mathrm{Cu}(\mathrm{II})$ and $\mathrm{Zn}(\mathrm{II})$ metal ions with the investigated ligands (L1 and L2) were prepared as described in the experimental section. The resulting complexes were subjected to elemental analysis for their C, H, N and metal content [14], infrared spectral studies (IR), nuclear magnetic resonance ${ }^{1} \mathrm{H}$ NMR, magnetic susceptibility, thermogravimetric analysis (TG and DTA), electronic absorption spectra, molar conductance and electron spin resonance (ESR) spectra. The results of elemental analysis which are listed in Tables 2 and 3 are in good agreement with those required by the proposed formula where in all cases 1:1 and 1:2 (M:L) solid complexes were isolated.

\subsection{Infrared spectra of the free ligands and their metal complexes}

The infrared spectra of the free ligands and solid complexes are recoded as $\mathrm{KBr}$ discs. In order to give conclusive idea about the structure of the solid complexes, the main IR bands were compared with those of the free ligands (Table 4). The strong broad band observed at 3496 and $3498 \mathrm{~cm}^{-1}$ in the spectra of the free ligands is assigned to $\mathrm{vOH}$. The $\mathrm{OH}$ stretching frequency appearing in the spectra of all complexes studies appeared as a broad band in the range $3114-3378 \mathrm{~cm}^{-1}$ is due to the presence of water of coordination and/or water of hydration. The bands in the 3122 and $3104 \mathrm{~cm}^{-1}$ region are due to Ar-H stretching vibration while those appeared in the 2821 and $2819 \mathrm{~cm}^{-1}$ region are due to aliphatic $\mathrm{C}-\mathrm{H}$ stretching vibration. The band appearing at 1670 and $1675 \mathrm{~cm}^{-1}$ are assigned to the stretching vibration of $\mathrm{C}=\mathrm{O}$ group. The IR spectra of the investigated ligands show the $-\mathrm{C}=\mathrm{C}$ - bands at $1602-1606 \mathrm{~cm}^{-1}$. The bands at 1488 and $1450 \mathrm{~cm}^{-1}$ are assigned to the stretching vibration of $\mathrm{N}=\mathrm{N}[16]$. Upon chelation a shift to lower wave number has been observed within the range 1380-1402 $\mathrm{cm}^{-1}$ indicating that it is a center of chelation. The bands appearing in the IR spectra of the ligands (L1 and L2) at $1267 \mathrm{~cm}^{-1}$ are assigned to the stretching vibration of $\mathrm{VC}-\mathrm{O}$. Upon chelation this band is shifted to lower wave number as shown in Tables 5 and 6 indicating that it may be considered as a center of chelation. The $\gamma_{\mathrm{CH}}$ of the aromatic rings is observed at 846 and $844 \mathrm{~cm}^{-1}$. In the infrared spectra of the ligands and complexes (Tables 3 and 4), the band observed in the range $1670-1695 \mathrm{~cm}^{-1}$ assigned to $\mathrm{vC}=\mathrm{O}$ while those in the range $1592-1610 \mathrm{~cm}^{-1}$ assigned to $\mathrm{vC}=\mathrm{C}$. The new IR bands appearing at 518-539 and $428-468 \mathrm{~cm}^{-1}$ are assignd to $(\mathrm{M} \leftarrow \mathrm{N})$ and $(\mathrm{M}-\mathrm{O})$ vibrations [17], respectively. In other words, these bands are possibly due to the formation of coordinated and covalent bonds between the donor atoms $(\mathrm{N}$ and $\mathrm{O}$ ) and the central metal ion. The most significant conclusive drawn from the proceeding arguments is that ligands L1 and L2 acts as bidentate ligands towards the central metal ion to form six-coordinate chelates.

\section{2. ${ }^{1} H$ NMR spectra of the investigated ligands and their $Z n$ complexes}

The ${ }^{1} \mathrm{H}$ NMR spectra of the investigated ligands (L1 and L2) and their $\mathrm{Zn}$ complexes (1:1 and 1:2) were recorded in DMSO as a solvent and tetramethylsilane (TMS) as an internal standard. The chemical shift values $(\delta)$ in ppm of the different types of protons in the investigated ligands (L1 and L2) are reported in Table 7. The ${ }^{1} \mathrm{H}$ NMR spectra of the investigated ligands L1 and L2 in DMSO exhibits a sharp signal at 10.52-10.51 $\mathrm{ppm}$. This signal is assigned to the proton of the $\mathrm{OH}$ group. The aliphatic protons of the methyl groups of the pyrone ring appeared at $2.35-2.36 \mathrm{ppm}$ while those observed at 2.19 and $3.87 \mathrm{ppm}$ are for aliphatic protons of the methyl and methoxy groups of the aromatic ring. The signals observed at $6.69-8.00 \mathrm{ppm}$ are assigned to the protons of the aromatic ring [18]. The signals observed at $6.12 \mathrm{ppm}$ are assigned to the proton of the pyrone ring [18]. A further support for the results obtained from the IR spectra is gained by considering the changes for the NMR spectra of the $\mathrm{Zn}$ complexes under investigation in comparison with those of the free ligands (Table 7).

For Zn-L1 (1:1 and 1:2) complexes, the disappearance of the signal at $10.52 \mathrm{ppm}$ indicates the involvement of the $\mathrm{OH}$ in chelation followed by a new signal at 3.75 and $3.74 \mathrm{ppm}$ corresponding to $\mathrm{H}_{2} \mathrm{O}$ of coordination and /or hydrated water in these complexes. These signals were not found in the spectra of the free ligands. The signal observed at $2.32 \mathrm{ppm}$ corresponding to $\mathrm{CH}_{3}$ in the pyrone ring for 1:1 and 1:2 complexes, while those observed at 2.15 and $2.49 \mathrm{ppm}$ corresponding to the aliphatic protons of $\mathrm{CH}_{3}$ group of the benzene ring for 1:1 and 1:2 complexes, 
For Zn-L2 (1:1 and 1:2) complexes, the signal at 10.51 corresponding to $\mathrm{OH}$ proton disappeared due to complexation with the appearance of a new signal in the region 3.56 and $3.59 \mathrm{ppm}$ due to coordinated water molecules. This signal was not obviously shown in the spectra of the free ligand. The singlet signal observed at 3.82 and 3.84 corresponding to the methoxy group for $1: 1$ and 1:2 complexes.

\subsection{Mass spectral studies of the investigated ligands and some of their complexes.}

Mass spectrometry permits the elucidation of molecular weight. Mass spectroscopy has proved extremely valuable for the determination of accurate molecular weights, obtaining molecular formulae, ionization potentials and bond strengths [19]. The observed peak at $\mathrm{m} / \mathrm{z} 294$ (calculated 294) represents the molecular ion peak of L1. The fragmentation pattern of this ligand can be regarded as general scheme showing the main fragmentation paths involved. The difference in the other ligand (L2) results from the effect of electronegativity of the substituent attached to the aromatic ring. For ligand L2, the main peak is observed at $\mathrm{m} / \mathrm{z} 310$ (calculated 310). From the data obtained we concluded that the molecular weights are in good agreement with the calculated values for the investigated ligands. The mass spectra of the some complexes were recorded and their molecular ion peaks confirm the suggested formula of these complexes. for Co-L1 (1:1), the main peak is observed at m/z 441 (calculated 441.4), Co-L1 (1:2) m/z 679 (calculated 680.9), Cu-L2 (1:1) m/z 461 (calculated 462.5), Cu-L2 (1:2) m/z 805 (calculated 807.5). The calculated values of the molecular weights of the investigated complexes are given with the corresponding elemental analysis in Tables 2 and 3.

\subsection{Thermogravimetric analysis (TG).}

The aim of the thermal analysis is to open up new possibilities for the investigation of metal complexes and to obtain information concerning the thermal stability of the divalent transition metal-azocoumarin complexes, establish whether the water molecules are inner or outer sphere if present and suggest the thermal decomposition of these complexes [13]. The TG curves follows the decrease in sample mass with the linear increase in temperature. In the present investigation, heating rates were suitably controlled at $10{ }^{\circ} \mathrm{C} \mathrm{min}^{-1}$ under nitrogen atmosphere and the mass loss followed up to $400^{\circ} \mathrm{C}$. From TG curves obtained, Figs. 1 and 2, the mass loss for each complex were calculated within the temperature range at which the loss occurs. The experimentally found and theoretically calculated mass losses are collected in Table 8.

For Cu-L1 (1:1) complex, two hydrated water molecules were expelled within the temperature range $60-120{ }^{\circ} \mathrm{C}$ corresponding to a loss of $7.25 \%$ (calculated $7.17 \%$ ). In the temperature range $120-220{ }^{\circ} \mathrm{C}$ one coordinated water molecule is expelled corresponding to a loss of $4.66 \%$ (calculated $4.04 \%$ ). In the temperature range $220-260{ }^{\circ} \mathrm{C}$ a weight loss of $8.79 \%$ (calculated $8.49 \%$ ) is observed corresponding to the loss of two coordinated water molecules and in the temperature range $260-360{ }^{\circ} \mathrm{C}$ a weight loss of $22.38 \%$ (calculated $22.19 \%$ ) is observed corresponding to the loss of one phenyl group. In the temperature range $360-380{ }^{\circ} \mathrm{C}$ a weight loss of $55.01 \%$ (calculated $55.33 \%$ ) is observed corresponding to the loss of $\mathrm{C}_{9} \mathrm{H}_{8} \mathrm{O}_{3} \mathrm{~N}_{2}$. At the end of the thermogram, the metal content was calculated from the residual metal oxide and found to be $17.45 \%$ (calculated $17.82 \%)$.

For $\mathrm{Cu}-\mathrm{L} 1(1: 2)$ complex, two hydrated water molecules were expelled within the temperature range $60-120^{\circ} \mathrm{C}$ corresponding to the loss of $5.34 \%$ (calculated 5.99\%). Two coordinated water molecules are expelled within the temperature range $120-240{ }^{\circ} \mathrm{C}$ corresponding to a loss of $5.62 \%$ (calculated $5.25 \%$ ). In the temperature range $240-310^{\circ} \mathrm{C}$ a weight loss of $16.50 \%$ (calculated 16.17\%) is observed corresponding to the loss of $\mathrm{C}_{6} \mathrm{H}_{5} \mathrm{~N}_{2}$. In the temperature range $310-370{ }^{\circ} \mathrm{C}$ a weight loss of $47.57 \%$ (calculated 47.41 ) is observed corresponding to the loss of $\mathrm{C}_{23} \mathrm{H}_{21} \mathrm{~N}_{2}$. At the end of the thermogram the metal content was calculated from the residual metal oxide which was found to be $11.47 \%$ (calculated $11.59 \%$ ).

For Mn-L2 (1:1) complex, one hydrated water molecule was expelled within the temperature range 80$130{ }^{\circ} \mathrm{C}$ corresponding to the loss of $3.94 \%$ (calculated 3.82\%). Three coordinated water molecule is expelled within the temperature range $130-290{ }^{\circ} \mathrm{C}$ corresponding to a loss of $11.64 \%$ (calculated $11.61 \%$ ). In the temperature range $290-370{ }^{\circ} \mathrm{C}$ a weight loss of $64.31 \%$ (calculated $64.35 \%$ ) is observed corresponding to a loss of $\mathrm{C}_{14} \mathrm{H}_{13} \mathrm{~N}_{2} \mathrm{O}_{3}$. At the end of the thermogram, the metal content was calculated from the residual metal oxide which was found to be $12.22 \%$ (calculated $12.11 \%$ ).

For Mn-L2 (1:2) complex, one hydrated water molecule was expelled within the temperature range 80140 corresponding to the loss of $2.66 \%$ (calculated 2.48). One coordinated water molecule was expelled within the temperature range $140-190{ }^{\circ} \mathrm{C}$ corresponding to a loss of $2.42 \%$ (calculated $2.54 \%$ ). In the temperature range $190-290^{\circ} \mathrm{C}$ a weight loss of $2.68 \%$ (calculated $2.61 \%$ ) was observed corresponding to the loss of another one coordinated water molecule, while in the temperature range $290-320{ }^{\circ} \mathrm{C}$ a weight loss of $11.99 \%$ (calculated $11.44 \%$ ) is observed corresponding to a loss of phenyl group and in the temperature range $320-360{ }^{\circ} \mathrm{C}$ a weight loss of $52.53 \%$ (calculated $53.60 \%$ ) is observed corresponding to the loss of $\mathrm{C}_{19} \mathrm{H}_{16} \mathrm{~N}_{4} \mathrm{O}$. At the end of the 
thermogram the metal content was calculated from the residual metal oxide which was found to be $10.32 \%$ (calculated 10.00).

\subsection{Differential thermal analysis (DTA)}

For Cu-L1 (1:1), the DTA curve is characterized by the presence of two endothermic peaks at the temperatures 100 and $169{ }^{\circ} \mathrm{C}$ which are due to the elimination of water of hydration and coordinated water molecules. For Cu-L1 (1:2), the DTA curve is characterized by the presence of five endothermic peaks at the temperatures $25,77,103,176$ and $265{ }^{\circ} \mathrm{C}$ which are due to the elimination of water of hydration and coordinated water molecules. For $\mathrm{Cu}-\mathrm{L} 1 \quad(1: 1$ and 1:2) an exothermic peak on the DTA curves at the temperatures 355 and $340{ }^{\circ} \mathrm{C}$ are observed due to the decomposition of the organic moiety followed by the formation of an intermediate species and rearrangement of the decomposed species. Raising the temperature than these temperatures results in another decomposition and combustion followed by decarbonization of the organic material and at the end there would be the metallic residue as $\mathrm{CuO}$.

For Mn-L2 (1:1), the DTA curve is characterized by the presence of four endothermic peaks at the temperatures $86,108,184$ and $272{ }^{\circ} \mathrm{C}$ which are due to the elimination of water of hydration and coordinated water molecules. For Mn-L2 (1:2), the DTA curve is characterized by the presence of five endothermic peaks at the temperatures $35,122,175,182$ and $271{ }^{\circ} \mathrm{C}$ which are due to the elimination of water of hydration and coordinated water molecules. For Mn-L2 (1:1 and 1:2) An exothermic peak on the DTA curves at the temperature $390{ }^{\circ} \mathrm{C}$ is observed due to the decomposition of the organic moiety followed by the formation of an intermediate species and rearrangement of the decomposed species. Raising the temperature than $390{ }^{\circ} \mathrm{C}$ results in the combustion followed by decarbonization of the organic material and at the end there would be the metallic residue as $\mathrm{MnO}$.

\subsection{Magnetic susceptibility measurements.}

The magnetic moment $(\mu)$ of a transition metal can give important information about the number of unpaired electrons in the metal ion, and in some special cases help to indicate the structure of the complex. Experimentally determined values of $\mu$ are in some cases higher than those calculated using the spin only approximation. Such is the case for some complexes, in which case orbital contribution cannot be neglected. The calculated magnetic moments of (1:1 and 1:2) (M:L) complexes of the investigated ligands (L1 and L2) with $\mathrm{Mn}^{2+}$ metal ion are in the range 5.55-5.95 B.M. indicating the presence of 5 unpaired electrons in the dorbital $\left(\mu_{\text {eff }}=5.91\right.$ B.M.) and show a high spin $\mathrm{d}^{5}$ configuration $\left(t_{2 g}^{3} e_{g}^{2}\right)$. For $\mathrm{Co}^{2+},(1: 1$ and $1: 2)$ (M:L) complexes with the investigated ligands (L1 and L2), the calculated magnetic moments of the complexes are in the range 3.84-3.91 B.M. indicating the presence of three unpaired electrons per metal ion ( $\mu_{\mathrm{eff}}=3.87$ B.M.). For $\mathrm{Ni}^{2+}\left(1: 1\right.$ and 1:2) $(\mathrm{M}: \mathrm{L})$, the complexes show $\mu_{\text {eff }}$ in the range 2.84-2.85 B.M. denoting two unpaired electrons ( $\mu_{\mathrm{eff}}=2.82$ B.M.) and showing paramagnetic properties for all of the investigated ligands (L1, L2). For $\mathrm{Cu}^{2+}$ complexes (1:1 and 1:2) (M:L) complexes, the calculated magnetic moments of the complexes are in the range 1.74-1.76 B.M. indicating the presence of one unpaired electron per metal ion in its d-orbital $\left(\mu_{\text {eff }}=1.73\right.$ B.M.). For $\mathrm{Zn}^{2+}$ (1:1 and 1:2) (M:L) complexes with the investigated ligands (L1 and L2), the calculated magnetic moments are in the range 0.06-0.08 B.M. indicating the absence of unpaired electrons and $\mathrm{Zn}^{2+}$ complexes show a diamagnetic properties. All of the metal ions $\left(\mathrm{Mn}^{2+}, \mathrm{Co}^{2+}, \mathrm{Ni}^{2+}\right.$ and $\left.\mathrm{Cu}^{2+}\right)$ complexes show paramagnetism, which means that the ligands have little effects on the metal ions field i.e. the ligands exhibit a weak field effect [20]. $\mathrm{Zn}^{2+}$ complexes show diamagnetic behavior since the d-orbitals are completely filled and thus $\mathrm{Zn}^{2+}$ considered as non-transition metal ion.

\subsection{Electron spin resonance (ESR).}

The X-band ESR spectra of $\mathrm{Cu}^{2+}$-azocoumarin complexes at room temperature generally show one, two or three broad signals depending on the nature of the ligands used and the type of the complexes formed, Table 9. Generally, the complexes are not magnetically dilute, therefore, exchanges [21] and/or dipolar forces are expected to operate in such a case, the $g$ anisotropy is likely to be reduced. The absence of hyperfine is taken as evidence of exchange as is the fact that

$$
\mathrm{G}=\mathrm{g}_{/ /}-2 / \mathrm{g}_{(\perp-2)}
$$

is lower than four [22] which could be attributed to octahedral symmetry around the $\mathrm{Cu}^{2+}$ ions. Moreover, the apparent broadening of the ESR signals may be due to an interaction between $\mathrm{Cu}^{2+}$ ions which are probably present in nonequivalent lattice position, the positive shift of $g$ values from that of the free electron (2.0023) indicates a high covalent character of the bonding between the $\mathrm{Cu}^{2+}$ ions and the azocoumarin ligands [23]. 


\subsection{Molar conductivity measurements.}

The molar conductivities of the solid complexes were measured for the 1:1 and 1:2 complexes in chloroform and are found in the range of $8.2-16.4 \mathrm{ohm}^{-1} \mathrm{~cm}^{2} \mathrm{~mol}^{-1}$. These values were measurably small for the ionic complexes of the divalent metal ions. These low conductivity values may be attributed to the presence of chloride ions in the coordination sphere rather than ionic association to the metal ions during complex formation and also no white precipitate is formed by the addition of $\mathrm{AgNO}_{3}$. This directly supports the fact that all of the investigated complexes are non-ionic or non electrolytes in nature [24]. The conductivity values for all of the investigated complexes are listed in Tables 6 and 7.

\subsection{Electronic absorption spectra of the ligands and some of their complexes.}

The electronic absorption spectra of the investigated ligands (L1 and L2), exhibit two bands at $330 \mathrm{~nm}$ $\left(30303 \mathrm{~cm}^{-1}\right)$ and $420 \mathrm{~nm}\left(20809 \mathrm{~cm}^{-1}\right)$, the first band may be assigned to the $\pi-\pi^{*}$ transition within the phenyl moiety and the second band may be ascribed to the $\mathrm{n}-\pi^{*}$ transitions within the $-\mathrm{N}=\mathrm{N}-$ followed by intramolecular charge (C.T.) or interligand transitions within the ligands. The electronic absorption spectra of the divalent $\mathrm{Mn}, \mathrm{Co}$, Ni and $\mathrm{Cu}$ metal ions with the investigated ligands (L1 and L2) (1:1) and (1:2) complexes exhibit two absorption bands at $220 \mathrm{~nm}\left(45454 \mathrm{~cm}^{-1}\right), 330 \mathrm{~nm}\left(30303 \mathrm{~cm}^{-1}\right)$ and a shoulder at $470 \mathrm{~nm}(21276$ $\mathrm{cm}^{-1}$ ) may be attributed to charge transfer ${ }^{2} \mathrm{~A}_{2 \mathrm{~g}} \rightarrow{ }^{2} \mathrm{~T}_{1 \mathrm{~g}}$ transitions [25-27] and an octahedral configuration was suggested around the central metal ion.

Based on the results of elemental analysis, IR, ${ }^{1} \mathrm{H}$ NMR, thermal analysis, electron spin resonance (ESR), magnetic moments calculations, mass spectra and electron absorpation spectra for the investigated complexes, The 1:1 and 1:2 complexes are isolated. The proposed steriochemical structures for the investigated metal complexes suggest octahedral geometry for $1: 1$ and $1: 2$ complexes.<smiles></smiles>

1:1 complexes

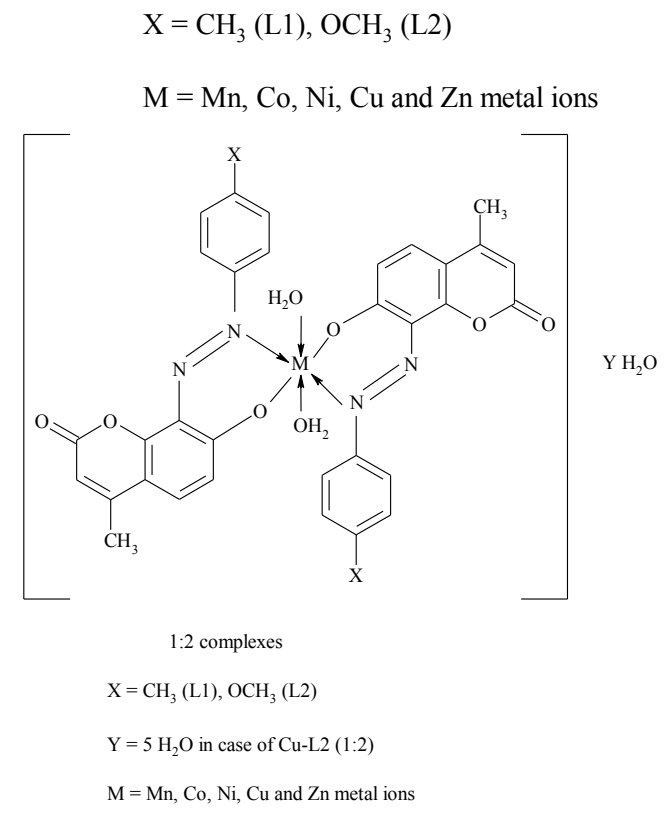




\section{Conclusion}

Some 8-arylazo coumarins have been prepared and fully characterized using different analytical tools. The metal complexes of the investigated ligands $\mathrm{L} 1$ and $\mathrm{L} 2$ with $\mathrm{Mn}^{2+}, \mathrm{Co}^{2+}, \mathrm{Ni}^{2+}, \mathrm{Cu}^{2+}$ and $\mathrm{Zn}^{2+}$ metal ions were prepared and subjected to elemental analysis, IR, ${ }^{1} \mathrm{H}$ NMR, mass spectra, Thermal analysis (TG and DTA), magnetic susceptibility, ESR spectra, molar conductance and electronic absorption spectra. The IR bands of the complexes were compared with those of the free ligands. The TG and DTA are documented. The weight losses for some complexes were calculated for the corresponding temperature ranges. The ${ }^{1} \mathrm{H}$ NMR spectra of the ligands and some of the prepared complexes are done and correlated. The magnetic susceptibility shows that all of the prepared complexes have high spin configuration. The molar conductance shows that all of the complexes are neutral or non-electrolytes in nature. ESR and electronic absorption spectra show that all of the prepared complexes have octahedral structures.

\section{References}

[1] G. J. Keating, R. O’Kennedy, In The Chemistry and Occurrence of Coumarins; R. O’Kennedy, R. D. Thornes Eds., John Wiley \& Sons West Sussex, England, 1997, p. 23.

[2] I. Kostova, Curr. Med. Chem., Anti-Cancer Agents, 5 (2005) 29-46.

[3] E. G. H. Shahinian, I. Haiduc, I. Sebe, UPB Sci. Bull., Series B: Chem. Mater. Sci., 73 (2011) 153-160.

[4] A. L. El-Ansary, E. M. Ebeid, M. M. Omar, Spectrochim. Acta, Part A, 43 (1987) 709-710.

[5] O. M. Abdelhafez, K. M. Amin, R. Z. Batran, T. J. Maher, S. A. Nada, S. Sethumadhavan, Bioorg. Med. Chem., 18 (2010) 3371-3378

[6] M. Cordaro, G. Grassi, F. Risitano, A. Scala, Tetrahedron, 66 (2010) 2713-1717.

[7] H. Çakici, A. A. Esenpinar, M. Bulut, Polyhedron, 27 (2008) 3625-3630.

[8] R. G. Kalkhambkar, G. M. Kulkarni, C. M. Kamanavalli, N. Premkumar, S. M. B. Asdaq, C. M. Sun, Eur. J. Med. Chem., 43 (2008) 2178-2188.

[9] T. J. Brett, J. M. Alexander, J. J. Stezowski, J. Chem. Soc., Perkin Trans. 2 (2000) 1095-1103.

[10] T. Yu, S. Yang, Y. Zhao, H. Zhang, X. Han, D. Fan, Y. Qiu, L. Chen, J. Photochem. Photobiol. A, Chemistry, 214 (2010) $92-$ 99.

[11] A. Alemdar, A. R. Özkaya, M. Bulut, Synth. Met., 160 (2010) 1556-1565.

[12] A. Z. El-Sonbati, R. M. Issa, A. M. Abd El-Gawad, Spectrochim. Acta, Part A, 68 (2007) 134-138.

[13] S. A. Abdel-Latif, H. B. Hassib, Y. M. Issa, Spectrochim. Acta, Part A, 67 (2007) 950-957.

[14] A. M. G., Macdonald, P. Sirichanya, Microchem. J., 14 (1969)199-206.

[15] J. D. Lee, A New Concise Inorganic Chemistry", $4^{\text {th }}$ Edition, Chapman and Hall Ltd, London, 1991 , p. 663.

[16] H. B. Hassib, S. A. Abdel-Latif, Spectrochim. Acta, Part A, 59 (2003) 2425-2434.

[17] A. A. A. Emara, Synth. React. Inorg. Met-org. Chem., 29 (1999) 87-103.

[18] J. R. Francisco, M. Valls, A. Virgili, Mag. Reson. Chem., 26 (1988) 511.

[19] O. E. Sherif, Omar M. M., Y. M. Issa, J. Therm. Anal., 39 (1993) 735-742.

[20] A. N. Speca, N. M. Karayannis, L. L. Pytlewski, Inorg. Chim. Acta, 9 (1974) 87-93.

[21] B. J. Hathaway, Coord. Chem. Rev., 41 (1982) 423-487.

[22] B. J. Hathaway, A. A. G. Tomlinson, Coord. Chem. Rev., 5 (1970) 1-43.

[23] I. Fidone, K. W. H. Stevens, Proc. Phys. Soc., 73 (1959) 116-117.

[24] T. M. A. Ismail, J. Coord. Chem., 59 (2006) 255-270.

[25] B. J. Hathaway, D. E. Billing, Coord. Chem. Rev., 5 (1970) 143-207.

[26] I. M. Procter, B. J. Hathaway, P. Hedsson, J. Inorg. Nucl. Chem., 34 (1972) 3689-.

Table 1

Analytical data of the prepared ligands L1 and L2

\begin{tabular}{|c|c|c|c|c|c|c|c|c|c|}
\hline $\begin{array}{l}\text { Ligan } \\
\text { d }\end{array}$ & $\mathrm{X}$ & Tentative formula & $\mathrm{mp}\left({ }^{\circ} \mathrm{C}\right)$ & Colour & $\begin{array}{l}\text { Molecular } \\
\text { weight }\end{array}$ & $\begin{array}{l}\text { Yield } \\
\%\end{array}$ & $\begin{array}{l}\mathrm{C} \% \\
\text { calculated } \\
\text { (found) }\end{array}$ & $\begin{array}{l}\mathrm{H} \% \\
\text { calculated } \\
\text { (found) }\end{array}$ & $\begin{array}{l}\mathrm{N} \% \\
\text { calculated } \\
\text { (found) }\end{array}$ \\
\hline $\mathrm{L} 1$ & $\mathrm{p}-\mathrm{CH}_{3}$ & $\mathrm{C}_{17} \mathrm{H}_{14} \mathrm{~N}_{2} \mathrm{O}_{3}$ & 150 & Orange red & 294 & 90 & $\begin{array}{l}69.39 \\
(69.37)\end{array}$ & $\begin{array}{l}4.76 \\
(4.73)\end{array}$ & $\begin{array}{l}9.52 \\
(9.26)\end{array}$ \\
\hline L2 & $\mathrm{p}-\mathrm{OCH}_{3}$ & $\mathrm{C}_{17} \mathrm{H}_{14} \mathrm{~N}_{2} \mathrm{O}_{4}$ & 156 & Orange red & 310 & 80 & $\begin{array}{l}65.80 \\
(65.97)\end{array}$ & $\begin{array}{l}4.51 \\
(4.10)\end{array}$ & $\begin{array}{l}9.03 \\
(9.31)\end{array}$ \\
\hline
\end{tabular}

Table 2

Elemental analysis, magnetic moments $\mu_{\text {eff }}$ and molar conductance $\Lambda_{\mathrm{m}}$ for the complexes of $\mathrm{Mn}^{2+}, \mathrm{Co}^{2+}, \mathrm{Ni}^{2+}$,

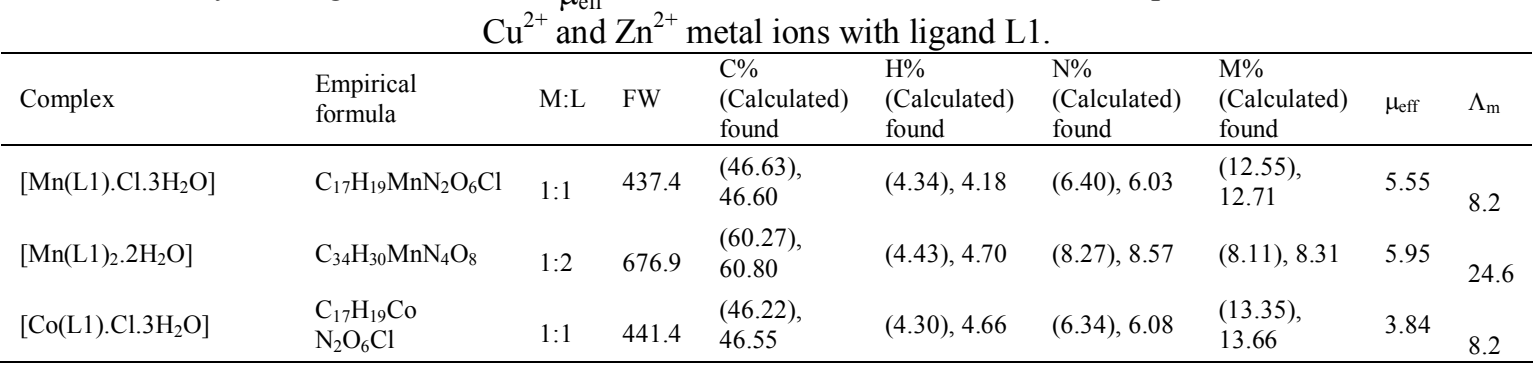


Spectroscopic, Thermal, Magnetic and conductimetric studies on some 7-hydroxy-4-methyl-8

\begin{tabular}{|c|c|c|c|c|c|c|c|c|c|}
\hline$\left[\mathrm{Co}(\mathrm{L} 1)_{2} .2 \mathrm{H}_{2} \mathrm{O}\right]$ & $\mathrm{C}_{34} \mathrm{H}_{30} \mathrm{Co} \mathrm{N}_{4} \mathrm{O}_{8}$ & $1: 2$ & 680.9 & $\begin{array}{l}(59.92), \\
58.00\end{array}$ & $(4.40), 4.30$ & $(8.22), 8.22$ & (8.65), 8.77 & 3.91 & 16.4 \\
\hline$\left[\mathrm{Ni}(\mathrm{L} 1) \cdot \mathrm{Cl} \cdot 3 \mathrm{H}_{2} \mathrm{O}\right]$ & $\mathrm{C}_{17} \mathrm{H}_{19} \mathrm{NiN}_{2} \mathrm{O}_{6} \mathrm{Cl}$ & $1: 1$ & 441.2 & $\begin{array}{l}(46.24), \\
46.00\end{array}$ & $(4.31), 4.40$ & $(6.34), 6.23$ & $\begin{array}{l}(13.30), \\
13.50\end{array}$ & 2.84 & 8.2 \\
\hline$\left[\mathrm{Ni}(\mathrm{L} 1)_{2} .2 \mathrm{H}_{2} \mathrm{O}\right]$ & $\mathrm{C}_{34} \mathrm{H}_{30} \mathrm{NiN}_{4} \mathrm{O}_{8}$ & $1: 2$ & 676.7 & $\begin{array}{l}(60.29) \\
60.88\end{array}$ & $(4.43), 4.22$ & $(8.27), 8.37$ & (8.67), 8.51 & 2.85 & 16.4 \\
\hline$\left[\mathrm{Cu}(\mathrm{L} 1) \cdot \mathrm{Cl} \cdot 3 \mathrm{H}_{2} \mathrm{O}\right] \cdot 2 \mathrm{H}_{2} \mathrm{O}$ & $\mathrm{C}_{17} \mathrm{H}_{23} \mathrm{CuN}_{2} \mathrm{O}_{8} \mathrm{Cl}$ & $1: 1$ & 482 & $\begin{array}{l}(42.32), \\
42.61\end{array}$ & $(4.77), 4.39$ & $(5.81), 6.51$ & $\begin{array}{l}(13.17) \\
14.55\end{array}$ & 1.74 & 8.2 \\
\hline$\left[\mathrm{Cu}(\mathrm{L} 1)_{2} \cdot 2 \mathrm{H}_{2} \mathrm{O}\right] \cdot 2 \mathrm{H}_{2} \mathrm{O}$ & $\mathrm{C}_{34} \mathrm{H}_{34} \mathrm{CuN}_{4} \mathrm{O}_{10}$ & $1: 2$ & 721.5 & $\begin{array}{l}(56.55), \\
56.32\end{array}$ & $(4.71), 4.67$ & (7.76), 7.47 & $(8.80), 8.22$ & 1.76 & 16.4 \\
\hline$\left[\mathrm{Zn}(\mathrm{L} 1) \cdot \mathrm{Cl} \cdot 3 \mathrm{H}_{2} \mathrm{O}\right]$ & $\mathrm{C}_{17} \mathrm{H}_{19} \mathrm{ZnN}_{2} \mathrm{O}_{6} \mathrm{Cl}$ & $1: 1$ & 447.8 & $\begin{array}{l}(45.55) \\
45.05\end{array}$ & $(4.24), 4.49$ & $(6.25), 6.71$ & $\begin{array}{l}(14.58), \\
14.45\end{array}$ & 0.06 & 8.2 \\
\hline$\left.\left[\mathrm{Zn}(\mathrm{L} 1)_{2} \cdot 2 \mathrm{H}_{2} \mathrm{O}\right)\right]$ & $\mathrm{C}_{34} \mathrm{H}_{30} \mathrm{ZnN}_{4} \mathrm{O}_{8}$ & $1: 2$ & 687.3 & $\begin{array}{l}(59.36), \\
59.09\end{array}$ & $(4.36), 4.89$ & (8.15), 8.09 & $(9.50), 9.44$ & 0.08 & 16.4 \\
\hline
\end{tabular}

Table 3

Elemental analysis, magnetic moments $\mu_{\mathrm{eff}}$ and molar conductance $\Lambda_{\mathrm{m}}$ for the complexes of $\mathrm{Mn}^{2+}, \mathrm{Co}^{2+}, \mathrm{Ni}^{2+}$,

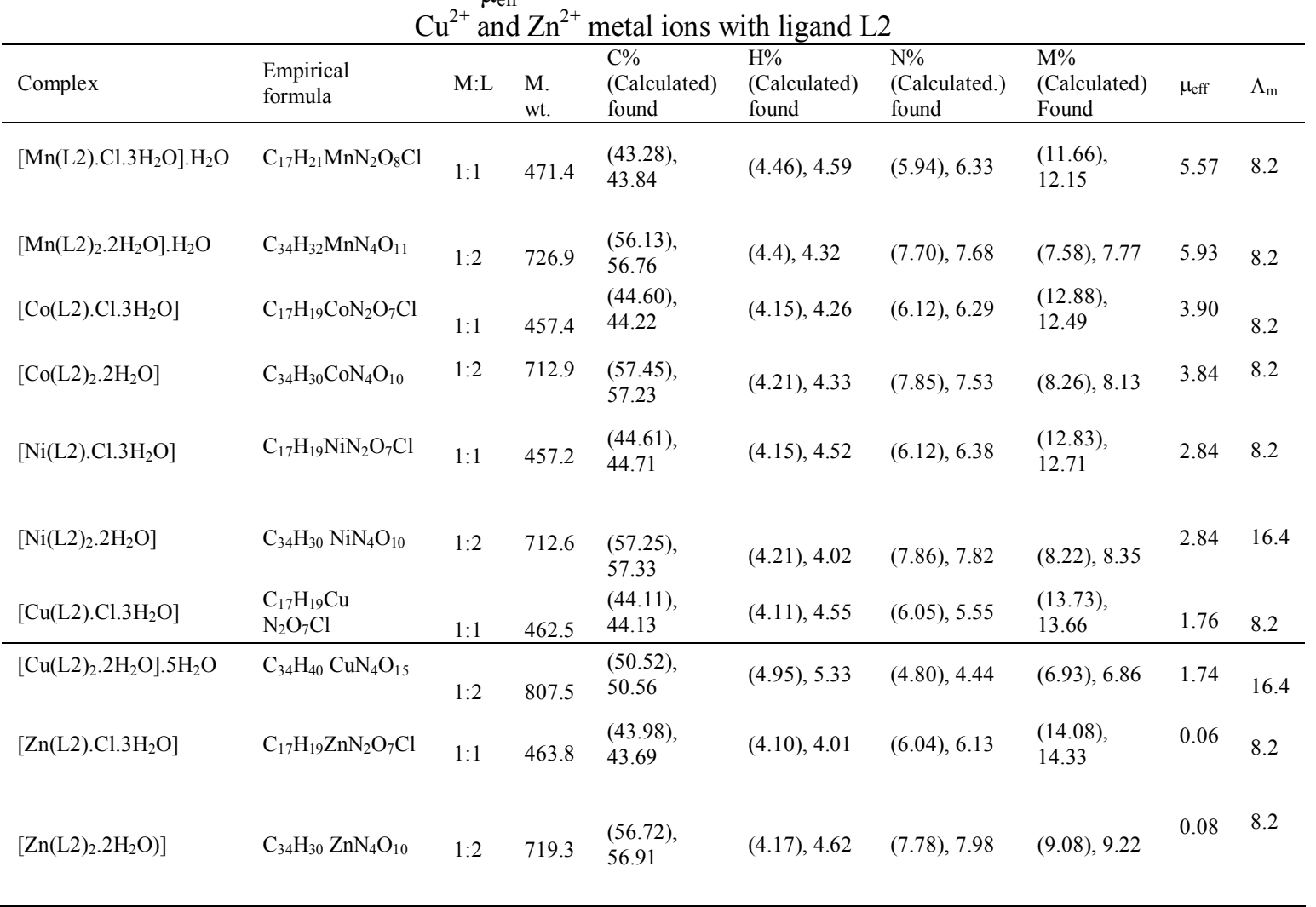

Table 4

IR band assignments of the investigated free ligands L1 and L2

\begin{tabular}{lll}
\hline L1 & L2 & Band Assignment \\
\hline 3498 & 3496 & $v_{\mathrm{OH}}$ \\
3122 & 3104 & $v_{\mathrm{C}-\mathrm{H} \text { aromatic }}$ \\
2821 & 2819 & $v_{\mathrm{C}-\mathrm{H} \text { aliphatic }}$ \\
1675 & 1670 & $v_{\mathrm{C}=\mathrm{O}}$ \\
1606 & 1606 & $v_{\mathrm{C}=\mathrm{C}}$ \\
1450 & 1450 & $v_{\mathrm{N}=\mathrm{N}}$ \\
1350 & 1350 & $v_{\mathrm{C}-\mathrm{H}}$ \\
1267 & 1267 & $v_{\mathrm{C}-\mathrm{O}}$ \\
1168 & 1267 & $v_{\mathrm{C}-\mathrm{H}}$ \\
1066 & 1066 & $\delta_{\mathrm{OH}}$ \\
846 & 846 & $\gamma_{\mathrm{C}-\mathrm{H}}$ \\
\hline
\end{tabular}


Table 5

IR band assignment of $\mathrm{Mn}^{2+}, \mathrm{Co}^{2+}, \mathrm{Ni}^{2+}, \mathrm{Cu}^{2+}$ and $\mathrm{Zn}^{2+}$ complexes with the investigated ligand $\mathrm{L} 1$

\begin{tabular}{lllllllll}
\hline Complex & $\mathrm{M}: \mathrm{L}$ & $v(\mathrm{OH})$ & $v(\mathrm{C}=\mathrm{O})$ & $v(\mathrm{C}=\mathrm{C})$ & $v(\mathrm{~N}=\mathrm{N})$ & $v(\mathrm{C}-\mathrm{O})$ & $v(\mathrm{M}-\mathrm{N})$ & $v(\mathrm{M}-\mathrm{O})$ \\
\hline$\left[\mathrm{Mn}(\mathrm{L} 1) \cdot \mathrm{Cl} \cdot 3 \mathrm{H}_{2} \mathrm{O}\right]$ & $1: 1$ & 3166 & 1681 & 1598 & 1382 & 1226 & 526 & 445 \\
& & & & & & & & \\
{$\left[\mathrm{Mn}(\mathrm{L} 1)_{2} \cdot 2 \mathrm{H}_{2} \mathrm{O}\right]$} & $1: 2$ & 3338 & 1685 & 1600 & 1382 & 1216 & 518 & 428 \\
{$\left[\mathrm{Co}(\mathrm{L} 1) \cdot \mathrm{Cl} \cdot 3 \mathrm{H}_{2} \mathrm{O}\right]$} & $1: 1$ & 3143 & 1681 & 1594 & 1382 & 1234 & 528 & 443 \\
{$\left[\mathrm{Co}(\mathrm{L} 1)_{2} \cdot 2 \mathrm{H}_{2} \mathrm{O}\right]$} & $1: 2$ & 3143 & 1681 & 1592 & 1382 & 1234 & 534 & 443 \\
{$\left[\mathrm{Ni}(\mathrm{L} 1) \cdot \mathrm{Cl} \cdot 3 \mathrm{H}_{2} \mathrm{O}\right]$} & $1: 1$ & 3160 & 1681 & 1594 & 1384 & 1226 & 532 & 445 \\
{$\left[\mathrm{Ni}(\mathrm{L} 1)_{2} \cdot 2 \mathrm{H}_{2} \mathrm{O}\right]$} & $1: 2$ & 3168 & 1681 & 1598 & 1390 & 1224 & 524 & 447 \\
{$\left[\mathrm{Cu}(\mathrm{L} 1) \cdot \mathrm{Cl}_{3} \cdot 3 \mathrm{H}_{2} \mathrm{O}\right] \cdot 2 \mathrm{H}_{2} \mathrm{O}$} & $1: 1$ & 3160 & 1677 & 1594 & 1402 & 1260 & 538 & 445 \\
{$\left[\mathrm{Cu}(\mathrm{L} 1)_{2} \cdot 2 \mathrm{H}_{2} \mathrm{O}\right] \cdot 2 \mathrm{H}_{2} \mathrm{O}$} & $1: 2$ & 3158 & 1681 & 1592 & 1382 & 1234 & 534 & 445 \\
{$\left[\mathrm{Zn}(\mathrm{L} 1) \cdot \mathrm{Cl} \cdot 3 \mathrm{H}_{2} \mathrm{O}\right]$} & $1: 1$ & 3176 & 1677 & 1608 & 1392 & 1260 & 526 & 468 \\
$\left.\left[\mathrm{Zn}(\mathrm{L} 1)_{2} \cdot 2 \mathrm{H}_{2} \mathrm{O}\right)\right]$ & $1: 2$ & 3114 & 1670 & 1606 & 1384 & 1260 & 539 & 466 \\
\hline
\end{tabular}

Table 6

IR band assignment of $\mathrm{Mn}^{2+}, \mathrm{Co}^{2+}, \mathrm{Ni}^{2+}, \mathrm{Cu}^{2+}$ and $\mathrm{Zn}^{2+}$ complexes with the investigated ligand $\mathrm{L} 2$

\begin{tabular}{|c|c|c|c|c|c|c|c|c|}
\hline Complex & $\begin{array}{l}\text { M: } \\
\text { L }\end{array}$ & $v(\mathrm{OH})$ & $\begin{array}{c}v(\mathrm{C}=\mathrm{O} \\
)\end{array}$ & $v(\mathrm{C}=\mathrm{C})$ & $\begin{array}{c}v(\mathrm{~N}=\mathrm{N} \\
)\end{array}$ & $v(\mathrm{C}-\mathrm{O})$ & $\begin{array}{c}v(\mathrm{M}- \\
\mathrm{N})\end{array}$ & $\begin{array}{c}v(\mathrm{M}- \\
\mathrm{O})\end{array}$ \\
\hline$\left[\mathrm{Mn}(\mathrm{L} 2) \cdot \mathrm{Cl} \cdot 3 \mathrm{H}_{2} \mathrm{O}\right] \cdot \mathrm{H}_{2} \mathrm{O}$ & $1: 1$ & 3158 & 1683 & 1594 & 1382 & 1236 & 532 & 430 \\
\hline$\left[\mathrm{Mn}(\mathrm{L} 2)_{2} \cdot 2 \mathrm{H}_{2} \mathrm{O}\right] \cdot \mathrm{H}_{2} \mathrm{O}$ & $1: 2$ & 3282 & 1695 & 1610 & 1380 & 1259 & 530 & 428 \\
\hline$\left[\mathrm{Co}(\mathrm{L} 2) \cdot \mathrm{Cl} \cdot 3 \mathrm{H}_{2} \mathrm{O}\right]$ & $1: 1$ & 3156 & 1683 & 1596 & 1382 & 1236 & 532 & 428 \\
\hline$\left[\mathrm{Co}(\mathrm{L} 2)_{2} \cdot 2 \mathrm{H}_{2} \mathrm{O}\right]$ & $1: 2$ & 3154 & 1683 & 1600 & 1384 & 1261 & 532 & 428 \\
\hline$\left[\mathrm{Ni}(\mathrm{L} 2) \cdot \mathrm{Cl} \cdot 3 \mathrm{H}_{2} \mathrm{O}\right]$ & $1: 1$ & 3378 & 1681 & 1610 & 1388 & 1261 & 534 & 445 \\
\hline$\left[\mathrm{Ni}(\mathrm{L} 2)_{2} \cdot 2 \mathrm{H}_{2} \mathrm{O}\right]$ & $1: 2$ & 3162 & 1681 & 1598 & 1382 & 1247 & 534 & 430 \\
\hline$\left[\mathrm{Cu}(\mathrm{L} 2) \cdot \mathrm{Cl} \cdot 3 \mathrm{H}_{2} \mathrm{O}\right]$ & $1: 1$ & 3160 & 1683 & 1602 & 1384 & 1259 & 534 & 443 \\
\hline$\left[\mathrm{Cu}(\mathrm{L} 2)_{2} .2 \mathrm{H}_{2} \mathrm{O}\right] .5 \mathrm{H}_{2} \mathrm{O}$ & $1: 2$ & 3328 & 1677 & 1606 & 1388 & 1251 & 536 & 466 \\
\hline$\left[\mathrm{Zn}(\mathrm{L} 2) \cdot \mathrm{Cl} \cdot 3 \mathrm{H}_{2} \mathrm{O}\right]$ & $1: 1$ & 3147 & 1677 & 1600 & 1400 & 1261 & 520 & 447 \\
\hline$\left.\left[\mathrm{Zn}(\mathrm{L} 2)_{2} .2 \mathrm{H}_{2} \mathrm{O}\right)\right]$ & $1: 2$ & 3160 & 1683 & 1600 & 1396 & 1261 & 528 & 445 \\
\hline
\end{tabular}

Table 7

${ }^{1} \mathrm{H}$ NMR spectral data of the investigated ligands (L1, L2) and their Zn complexes

\begin{tabular}{|c|c|c|}
\hline Ligands and complexes & Chemical Shift $(\delta)$ & Assignment \\
\hline \multirow{7}{*}{ L1 } & 10.52 & $\mathrm{OH}$ \\
\hline & $8.00-6.69$ & Aromatic $\mathrm{C}-\mathrm{H}$ protons \\
\hline & 6.12 & Pyrone ring $\mathrm{C}-\mathrm{H}$ \\
\hline & 3.36 & $\mathrm{H}_{2} \mathrm{O}$ solvent protons \\
\hline & 2.50 & DMSO protons \\
\hline & 2.35 & $\mathrm{CH}_{3}$ pyrone ring \\
\hline & 2.19 & $\mathrm{CH}_{3}$ benzene ring \\
\hline \multirow{7}{*}{ L2 } & 10.51 & $\mathrm{OH}$ \\
\hline & $7.60-6.69$ & Aromatic $\mathrm{C}-\mathrm{H}$ protons \\
\hline & 6.12 & Pyrone ring $\mathrm{C}-\mathrm{H}$ \\
\hline & 3.87 & $\mathrm{OCH}_{3}$ benzen ring \\
\hline & 3.37 & $\mathrm{H}_{2} \mathrm{O}$ solvent protons \\
\hline & 2.51 & DMSO protons \\
\hline & 2.36 & $\mathrm{CH}_{3}$ pyrone ring \\
\hline $\begin{array}{c}\text { Zn-L1 } \\
(1: 1)\end{array}$ & $\begin{array}{c}7.53-6.62 \\
6.01 \\
3.75\end{array}$ & $\begin{array}{l}\text { Aromatic C-H protons } \\
\text { Pyrone ring C-H } \\
\mathrm{H}_{2} \mathrm{O} \text { of coordination DMSO protons }\end{array}$ \\
\hline
\end{tabular}


Spectroscopic, Thermal, Magnetic and conductimetric studies on some 7-hydroxy-4-methyl-8

\begin{tabular}{|c|c|c|}
\hline & $\begin{array}{l}2.50 \\
2.32 \\
2.15 \\
\end{array}$ & $\begin{array}{l}\mathrm{CH}_{3} \text { pyrone ring } \\
\mathrm{CH}_{3} \text { benzene ring }\end{array}$ \\
\hline $\begin{array}{c}\mathrm{Zn}-\mathrm{L} 1 \\
(1: 2)\end{array}$ & $\begin{array}{c}7.55-6.65 \\
6.05 \\
3.74 \\
2.50 \\
2.32 \\
2.49 \\
\end{array}$ & $\begin{array}{l}\text { Aromatic } \mathrm{C}-\mathrm{H} \text { protons } \\
\text { Pyrone ring } \mathrm{C}-\mathrm{H} \\
\mathrm{H}_{2} \mathrm{O} \text { of coordination } \\
\text { DMSO protons } \\
\mathrm{CH}_{3} \text { pyrone ring } \\
\mathrm{CH}_{3} \text { benzene ring }\end{array}$ \\
\hline $\begin{array}{c}\mathrm{Zn}-\mathrm{L} 2 \\
(1: 1)\end{array}$ & $\begin{array}{c}7.47-6.56 \\
5.94 \\
3.56 \\
3.82 \\
2.50 \\
2.31 \\
\end{array}$ & $\begin{array}{l}\text { Aromatic C-H protons } \\
\text { Pyrone ring } \mathrm{C}-\mathrm{H} \\
\mathrm{H}_{2} \mathrm{O} \text { of coordination } \\
\mathrm{OCH}_{3} \text { benzene ring } \\
\text { DMSO protons } \\
\mathrm{CH}_{3} \text { pyrone ring }\end{array}$ \\
\hline $\begin{array}{c}\mathrm{Zn}-\mathrm{L} 2 \\
(1: 2)\end{array}$ & $\begin{array}{c}7.53-6.62 \\
6.00 \\
3.59 \\
3.84 \\
2.50 \\
2.38 \\
2.33\end{array}$ & $\begin{array}{l}\text { Aromatic } \mathrm{C}-\mathrm{H} \text { protons } \\
\text { Pyrone ring } \mathrm{C}-\mathrm{H} \\
\mathrm{H}_{2} \mathrm{O} \text { of coordination } \\
\mathrm{OCH}_{3} \text { benzene ring } \\
\text { DMSO protons } \\
\mathrm{CH}_{3} \text { pyrone ring } \\
\mathrm{CH}_{3} \text { pyrone ring }\end{array}$ \\
\hline
\end{tabular}

Table 8

Thermogravimetric results of $\mathrm{Mn}^{2+}$ and $\mathrm{Cu}^{2+}$ complexes with the investigated ligands L1 and L2

\begin{tabular}{|c|c|c|c|c|c|}
\hline Complex & $\begin{array}{l}\text { Molecular } \\
\text { weight }\end{array}$ & Temperature $\left({ }^{\circ} \mathrm{C}\right)$ & $\begin{array}{l}\text { Calculated loss } \\
\%\end{array}$ & $\begin{array}{l}\text { Found loss } \\
\%\end{array}$ & Assignment \\
\hline $\begin{array}{l}{\left[\mathrm{Cu}(\mathrm{L} 1) \cdot \mathrm{Cl} \cdot 3 \mathrm{H}_{2} \mathrm{O}\right] \cdot 2 \mathrm{H}_{2} \mathrm{O}} \\
{\left[\mathrm{Cu}(\mathrm{L} 1) \cdot \mathrm{Cl} \cdot 3 \mathrm{H}_{2} \mathrm{O}\right]} \\
{\left[\mathrm{Cu}(\mathrm{L} 1) \cdot \mathrm{Cl} \cdot 2 \mathrm{H}_{2} \mathrm{O}\right]} \\
{[\mathrm{Cu}(\mathrm{L} 1) \cdot \mathrm{Cl}]}\end{array}$ & $\begin{array}{l}482 \\
446 \\
424 \\
347 \\
155\end{array}$ & $\begin{array}{l}60-120 \\
120-220 \\
220-260 \\
260-360 \\
360-380 \\
380-400\end{array}$ & $\begin{array}{l}7.17 \\
4.04 \\
8.49 \\
22.19 \\
55.33 \\
17.82\end{array}$ & $\begin{array}{l}7.25 \\
4.66 \\
8.79 \\
22.38 \\
55.01 \\
17.45\end{array}$ & $\begin{array}{l}2 \mathrm{H}_{2} \mathrm{O} \\
\mathrm{H}_{2} \mathrm{O} \\
2 \mathrm{H}_{2} \mathrm{O} \\
\mathrm{C}_{6} \mathrm{H}_{5} \\
\mathrm{C}_{9} \mathrm{H}_{8} \mathrm{O}_{3} \mathrm{~N}_{2} \\
\mathrm{CuO}\end{array}$ \\
\hline $\begin{array}{l}\left.\left[\mathrm{Cu}(\mathrm{L} 1)_{2}\right] \cdot 2 \mathrm{H}_{2} \mathrm{O}\right] \cdot 2 \mathrm{H}_{2} \mathrm{O} \\
\left.\left[\mathrm{Cu}(\mathrm{L} 1)_{2}\right] \cdot 2 \mathrm{H}_{2} \mathrm{O}\right] \\
{[\mathrm{Cu}(\mathrm{L} 1)]_{2}}\end{array}$ & $\begin{array}{l}721.5 \\
685.5 \\
649.5 \\
544.5\end{array}$ & $\begin{array}{l}60-120 \\
120-240 \\
240-310 \\
310-370 \\
370-400\end{array}$ & $\begin{array}{l}4.99 \\
5.25 \\
16.17 \\
47.41 \\
11.59\end{array}$ & $\begin{array}{l}5.34 \\
5.62 \\
16.50 \\
47.57 \\
11.47\end{array}$ & $\begin{array}{l}2 \mathrm{H}_{2} \mathrm{O} \\
2 \mathrm{H}_{2} \mathrm{O} \\
\mathrm{C}_{6} \mathrm{H}_{5} \mathrm{~N}_{2} \\
\mathrm{C}_{23} \mathrm{H}_{21} \mathrm{~N}_{2} \\
\mathrm{CuO}\end{array}$ \\
\hline $\begin{array}{l}{\left[\mathrm{Mn}(\mathrm{L} 2) \cdot \mathrm{Cl} \cdot 3 \mathrm{H}_{2} \mathrm{O}\right] \cdot \mathrm{H}_{2} \mathrm{O}} \\
{\left[\mathrm{Mn}(\mathrm{L} 2) \cdot \mathrm{Cl} \cdot 3 \mathrm{H}_{2} \mathrm{O}\right]} \\
{[\mathrm{Mn}(\mathrm{L} 2) \cdot \mathrm{Cl}]}\end{array}$ & $\begin{array}{l}471.4 \\
453.4 \\
399.4\end{array}$ & $\begin{array}{l}80-130 \\
130-290 \\
290-370 \\
370-400\end{array}$ & $\begin{array}{l}3.82 \\
11.91 \\
64.35 \\
12.11\end{array}$ & $\begin{array}{l}3.94 \\
11.64 \\
64.31 \\
12.22\end{array}$ & $\begin{array}{l}\mathrm{H}_{2} \mathrm{O} \\
3 \mathrm{H}_{2} \mathrm{O} \\
\mathrm{C}_{14} \mathrm{H}_{13} \mathrm{~N}_{2} \mathrm{O}_{3} \\
\mathrm{MnO}\end{array}$ \\
\hline $\begin{array}{l}\left.\mathrm{Mn}(\mathrm{L} 2)_{2} \cdot 2 \mathrm{H}_{2} \mathrm{O}\right] \cdot \mathrm{H}_{2} \mathrm{O} \\
\left.\mathrm{Mn}(\mathrm{L} 2)_{2} \cdot 2 \mathrm{H}_{2} \mathrm{O}\right] \\
\left.\mathrm{Mn}(\mathrm{L} 2)_{2} \cdot \mathrm{H}_{2} \mathrm{O}\right] \\
\left.\mathrm{Mn}(\mathrm{L} 2)_{2}\right]\end{array}$ & $\begin{array}{l}726.9 \\
708.9 \\
690.9 \\
672.9 \\
356.9\end{array}$ & $\begin{array}{l}80-140 \\
140-190 \\
190-290 \\
290-320 \\
320-360 \\
360-400\end{array}$ & $\begin{array}{l}2.48 \\
2.54 \\
2.61 \\
11.44 \\
53.60 \\
10.00\end{array}$ & $\begin{array}{l}2.66 \\
2.42 \\
2.68 \\
11.99 \\
53.53 \\
10.32 \\
\end{array}$ & $\begin{array}{l}\mathrm{H}_{2} \mathrm{O} \\
\mathrm{H}_{2} \mathrm{O} \\
\mathrm{H}_{2} \mathrm{O} \\
\mathrm{C}_{6} \mathrm{H}_{5} \\
\mathrm{C}_{19} \mathrm{H}_{16} \mathrm{~N}_{4} \mathrm{O} \\
\mathrm{MnO}\end{array}$ \\
\hline
\end{tabular}

Table 9

ESR spectral data of $\mathrm{Cu}^{2+}$ complexes with the investigated ligands $\mathrm{L} 1$ and $\mathrm{L} 2$.

\begin{tabular}{lccc}
\hline \multicolumn{1}{c}{ Complex } & $\mathrm{M}: \mathrm{L}$ & $\mathrm{g}_{\mathrm{z}}=\mathrm{g}_{/ /}$ & $\mathrm{g}_{\mathrm{x}}=\mathrm{g}_{\perp}$ \\
\hline$\left[\mathrm{Cu}(\mathrm{L} 1) \cdot \mathrm{Cl} \cdot 3 \mathrm{H}_{2} \mathrm{O}\right] \cdot 2 \mathrm{H}_{2} \mathrm{O}$ & $1: 1$ & $2.0549,2.113$ & 2.2438 \\
{$\left[\mathrm{Cu}(\mathrm{L} 1)_{2} \cdot 2 \mathrm{H}_{2} \mathrm{O}\right] .2 \mathrm{H}_{2} \mathrm{O}$} & $1: 2$ & $2.0663,2.1634$ & 2.2446 \\
{$\left[\mathrm{Cu}(\mathrm{L} 2) \cdot \mathrm{Cl}_{2} 3 \mathrm{H}_{2} \mathrm{O}\right]$} & $1: 1$ & $2.0477,2.1129$ & 2.2228 \\
{$\left[\mathrm{Cu}(\mathrm{L} 2)_{2} \cdot 2 \mathrm{H}_{2} \mathrm{O}\right] \cdot 5 \mathrm{H}_{2} \mathrm{O}$} & $1: 2$ & $2.0558,2.1129$ & 2.2281 \\
\hline
\end{tabular}

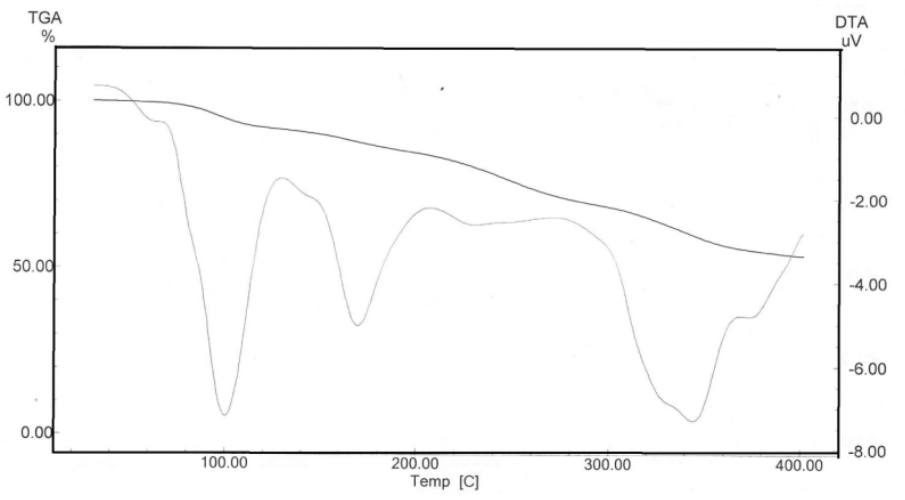

(a) 


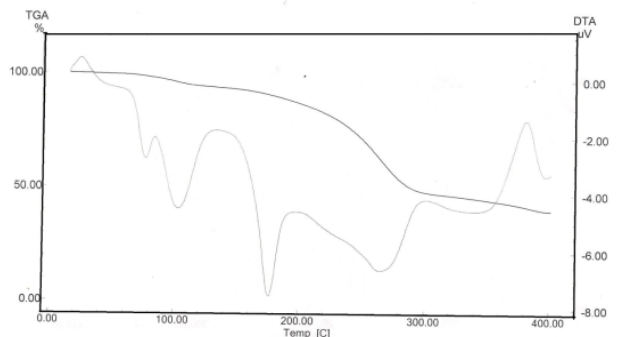

Fig. 1. Thermogravimetric and differential thermal analysis curves of $\mathrm{Cu}-\mathrm{L} 1$ (1:1) (a) and (1:2) (b) complexes

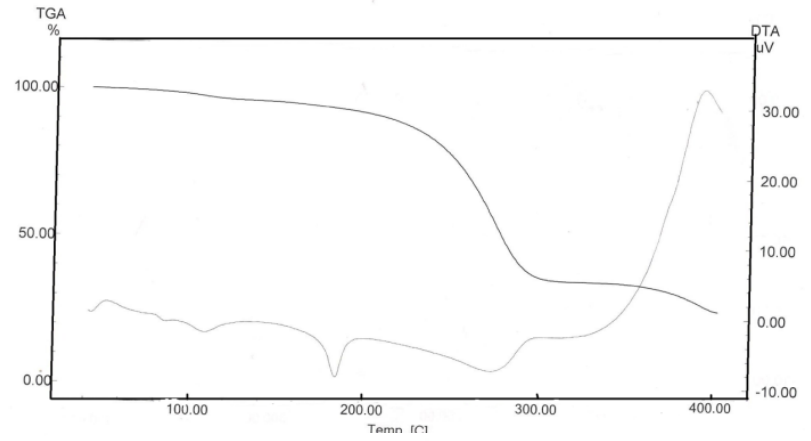

(a)

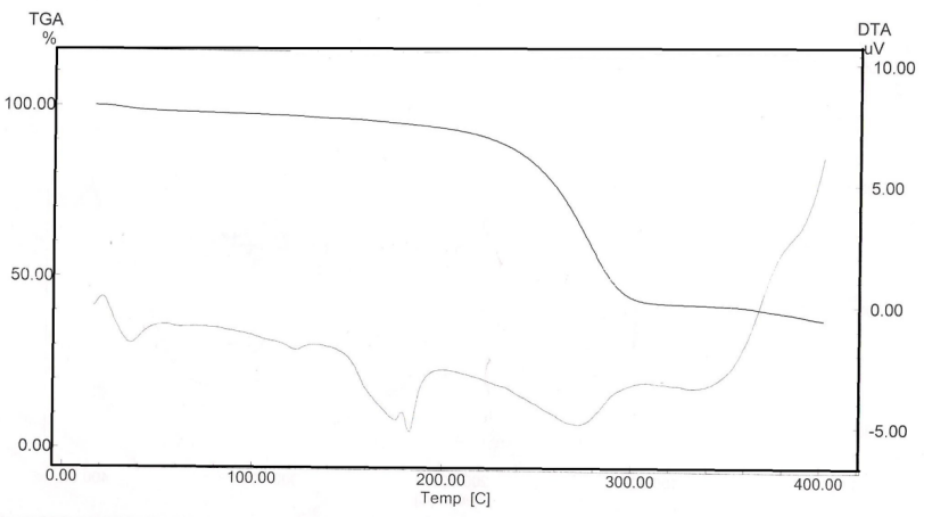

(b)

Fig. 2. Thermogravimetric and differential thermal analysis curves of Mn-L2 (1:1) (a) and (1:2) (b) complexes 